Article

\title{
Comparing Motivation-Based and Motivation-Attitude-Based Segmentation of Tourists Visiting Sensitive Destinations
}

\author{
Yoonjeong Jeong ${ }^{1}$, Seweryn Zielinski ${ }^{1}$, Ji-soon Chang ${ }^{2}$ and Seong-il Kim ${ }^{1,3, *}$ \\ 1 Department of Forest Sciences, Seoul National University, Seoul 08826, Korea; yoonjeong522@snu.ac.kr (Y.J.); \\ sew.zielinski@snu.ac.kr (S.Z.) \\ 2 Institute of International Cooperation Development, Seoul 04522, Korea; chzang@hotmail.com \\ 3 Research Institute of Agriculture and Life Sciences, Seoul National University, Seoul 08826, Korea \\ * Correspondence: seongil@snu.ac.kr; Tel.: +82-2-880-4765
}

Received: 31 August 2018; Accepted: 4 October 2018; Published: 10 October 2018

check for updates

\begin{abstract}
This study aims to compare motivation-based and motivation-attitude-based segmentation of tourist markets, by identifying the heterogeneity of both solutions. A k-means cluster analysis was conducted to segment markets, using the data collected from 722 respondents, via an onsite survey of visitors to the Kuang Si Waterfall and Konglor Cave in Lao People's Democratic Republic. Subsequently, socio-demographic and trip-related characteristics among the segments were compared using ANOVA and Chi-square tests. Both motivation-based and motivation-attitude-based segmentation each generated four distinctive segments. Although both solutions are viable for segmentation, the latter was found to be more useful in separating segments than the former, as its segments were significantly more distinguishable from each other in terms of socio-demographic and trip-related characteristics. This result contributes to the body of research on the comparison of market segmentation techniques, which is a rarely investigated topic.
\end{abstract}

Keywords: sustainable tourism; responsible tourist; market segmentation; Laos

\section{Introduction}

The tourism policy in Lao People's Democratic Republic (PDR) has centered on developing the cultural, natural, and historical tourism areas since 1986, the country's open door policy was first introduced [1,2]. These tourism areas usually feature outstanding natural and cultural environments, but they are generally located in the most remote and poorest areas in the country. Thus, the government has been encouraging the involvement of local communities in tourism development as a way of alleviating poverty and increasing the integration of remote regions of Lao PDR into the national market economy [3].

The number of international tourists visiting Lao PDR has rapidly increased. In 1990, the country received only 14,400 tourists, but this number was 4.2 million in 2016 and is now expected to reach 5.8 million by 2020 [4]. As a large number of diverse tourists currently visit Lao PDR, there is a growing realization of the importance of building knowledge on tourists in the country [2]. Knowing visitors' characteristics is especially important for the sustainable management of sensitive tourism destinations $[5,6]$. However, only a handful of tourist market studies have been conducted in the country.

This study examines motivation and attitudes toward responsible behavior of visitors to sensitive tourism areas in Lao PDR. It adapts Puhakka's [7] definition of responsible environmental behavior, but extends it by adding the missing sociocultural aspect. Responsible behavior occurs when tourists understand the impact of their behavior on the environment and local people, and abide by the 
sociocultural and environmental norms of the site. The term "sensitive tourism area" refers to destinations that support responsible tourism, but do not necessarily have all the characteristics of "ecotourism" or "responsible tourism" destinations, as provided in their common definitions. Motivation was used to segment tourists and provide information about their needs and desires, while attitudes added a layer to the segmentation to define the desired "responsible" markets for the sustainable management of sensitive tourism destinations. This study contributes to the discussion on segmentation methods using attitudes and motivations by comparing two solutions and identifying the most suitable one. To the best of the authors' knowledge, it is also the first paper that uses motivations and attitudes together to identify the most desirable market.

\section{Bases for Market Segmentation: Motivation and Attitudes}

Market segmentation is an activity that involves extracting homogenous markets with similar characteristics. In tourism, market segmentation allows marketers to understand the needs and wants of different travel groups and to efficiently communicate with them. In other words, it helps marketers identify marketing opportunities and develop tailor-made products and services aimed at specific customers [8]. Segmentation criteria employed in the tourism literature are geographic characteristics, demographics, psychographics, and behavioral factors including motivation, benefit sought, travel activity, and expenditure [9]. Of these, motivation is considered to be one of the most popular segmentation approaches [10].

Tourist motivation is "the combination of needs and desires that affect the propensity to travel" [11] (p. 247), and therefore, knowledge about motivation can assist managers in providing facilities and services that fulfill visitors' desires [10]. For these reasons, researchers have focused their attention on defining various tourist motivations. Scholars have mainly conducted research to understand tourists' general motivations (e.g., [12-16]) and destination-specific motivations (e.g., [17-20]). As noted by Pearce and Lee [13], the core motivation factors can be grouped into four categories: escape, relaxation, relationship enhancement, and self-development. In particular, motivations of tourists who visit nature-based tourism or ecotourism destinations are categorized into the following: escape, cohesion, healthy activity, and learning about nature $[17,21,22]$.

However, while knowing visitors' motivation and desires is critical, it is also important to target particular groups of tourists that meet destination management criteria. As noted by Pesonen [23], the results of segmentation must be used by destination managers to select segments corresponding with their management goals. Especially with regard to sensitive tourism areas, it is vital to find eco-friendly tourist segments for selective marketing [5]. This particular strategy was proposed by a number of authors (e.g., [20,24-27]).

Additionally, ethics underpin many of the decisions made by people, and, in particular, the concept of sustainability. Anthropogenic impacts and the resulting changes have led to the questioning and reevaluation of ethical positions toward the environment [28]. Relatively new forms of sustainable tourism, such as ecotourism or responsible tourism, rely on ethical behavior of tourists and tourism providers toward, not only the environment, but also the people. Ethical tourism is defined as "tourism in which all stakeholders involved apply principles of good behavior (justice, fairness and equality), to their interactions with one another, with society, with the environment and other life forms" [29] (p. 6). An individuals' ethics are influenced by his or her values, that is, the underlying guiding principles that influence the way a person feels about an object or situation [30].

Attitudes refer to the knowledge involving belief or disbelief about an object including people, items, services, issues, and concepts [31]. It is the way a person expresses or applies his or her beliefs and values. Many scholars have used environmental attitudes in finding eco-friendly tourist segments since it has been regarded as one of the key determinants of environmentally responsible behavior [32]. For instance, Formica and Uysal [24] segmented visitors to Virginia in the USA, based on the New Environmental Paradigm (NEP)—a scale measuring one's general "environmental worldview" developed by Dunlap and Van Liere [33]—into three distinct markets: "Conservationist," 
"Anthropocentric," and "Optimists." They then suggested that "Conservationists" are the most environmentally conscious tourists. Higham et al. [34] used the same scale to distinguish the environmental values of visitors to ecotourism operations in New Zealand. They found that "ecocentric rather than anthropocentric values featured prominently in the New Zealand ecotourism visitor profile." On the other hand, Zografos and Allcroft [35] used an updated NEP, called the New Ecological Paradigm, in the UK to identify four segments with a range of anthropocentric and ecocentric values. Their results indicated that demand for ecotourism is not confined to ecocentric segments and that biodiversity protection is prioritized by all segments. Similarly, Fairweather, Maslin, and Simmons [25] used general environmental attitudes as a segmentation base to identify which respondents can be considered as environmentally responsible tourists, which they then referred to as target segments for environmentally sustainable management.

Although earlier studies tend to use general environmental attitudes for segmentation, recent studies have focused more on attitudes toward specific environmental issues (e.g., [32,36-39]). This is in line with a widely accepted notion that individuals' attitudes toward specific behavioral norms or a particular issue is more consistent with their actual behavior than their attitudes toward general issues [32]. Kim and Weiler [32], for example, examined the specific environmental attitudes of tourists visiting the Charmouth coastal area in England. They found two different segments, "high environmental attitude" and "low environmental attitude," showing different attitudes toward responsible fossil collection. Similar studies that used specific attitudes include those that examined visitors' attitudes toward tourism development and the protection of hinterland in Australia [36], and tourists' attitudes toward low impact behavior protecting turtles and their habitats in the Mon Repos Conservation Park in Australia [37]. Wang, Li, and Liu [38] used multidimensional environmental value orientations as segmentation bases for analyzing a natural destination tourism market of the National Forest Recreation Areas in Taiwan. They identified two segments: acceptance and conditionality. The former refers to potential ecotourists who recognize the commercial value of natural resources, while the latter do not possess a strong sense of ecotourism, given that its favored services can affect the environment. Castellanos-Verdugo, Vega-Vázquez, Oviedo-García, and Orgaz-Agüera [39] confirmed the notion that attitudes toward ecotourism explain the perceived value of the tourist site, which largely predicts tourist satisfaction. All five aforementioned studies concluded that segments with eco-friendly attitudes differed significantly in many socio-demographic and travel characteristics, from other segments.

Although these aforementioned studies demonstrated the usefulness of specific environmental attitudes in sensitive tourism market segmentation, their contribution was centered on environmental aspects alone $[24,25,32,34-43]$. Therefore, their implications can be somewhat limited. In the case of sensitive tourism areas in developing countries, destinations are usually valued by visitors for their outstanding natural environment, as well as the provision of cultural aspects through local community involvement. One of the common management goals of these areas is conserving nature and the culture of the community. Another important goal is to improve the economic benefits to local communities. Therefore, when it comes to sensitive tourism market segmentation, sociocultural and economic responsibility toward the local community should also be taken into consideration $[27,44-49]$ and used as a base for segmentation.

Based on the gaps apparent in the literature, this study seeks to find whether attitudes toward behavior concerning the three aspects-environmental, sociocultural, and economic-are useful in sensitive tourism market segmentation. In order to answer this research question, the present study compares differences in the socio-demographic and trip-related characteristics of motivation-based segments and motivation-attitude-based segments. This study consequently contributes to segmentation theory in two ways: (1) by being one of the first studies to use attitudes involving both natural and cultural aspects as bases for market segmentation, and (2) by investigating whether motivation-attitude-based segmentation provides a better understanding of tourists, as opposed to only motivation-based segmentation. The results are also useful to managers of sensitive tourism destinations, especially to those who are considering selective marketing strategies in their sustainable tourism management planning. 


\section{Materials and Methods}

\subsection{Research Sites}

\subsubsection{Kuang Si Falls (KSF)}

The Kuang Si Falls (KSF) is a three-tier waterfall located $30 \mathrm{~km}$ south of Luang Prabang city and is part of a Provincial Protected Area (the Tat Kuang Si Park) (Figure 1). Since its public opening in 1987, the park has gradually developed and become one of the province's most prized natural assets. In the park, tourists can appreciate the great scenery of the KSF and the moist evergreen forest attracting diverse and rare wildlife, including various species of snakes, squirrels, and birds. They can also see the Asiatic Black Bear at the Tat Kuang Si Bear Rescue Center located near the entrance of the park. The main activities in the park include swimming and trying local cuisine made by local people living in or near the park (e.g., Thaphene village). To enter the park, visitors need to pay an admission fee (approximately US \$2.5 per person), which is used for park operation and maintenance.

\subsubsection{Konglor Cave (KC)}

Khammouane province is located in central Laos and has three national protected areas (NPAs) that cover a significant area of approximately $6285 \mathrm{~km}^{2}$ (Figure 1). With the purpose of poverty reduction and conservation of natural and cultural resources in the NPAs, an ecotourism project was initiated in 2002 under the Lao National Tourism Administration and the Khammouane Provincial Tourism Department. One of the remarkable projects has been carried out in Konglor village, located in the Phou Hinboun National Protected Area, $310 \mathrm{~km}$ southeast of Vientiane. In the surroundings of the village, there is a popular attraction, the largest cave in the country, called Konglor Cave (KC). The Hinboun River flows through a $7.5 \mathrm{~km}$ long cave tunnel that is approximately $30 \mathrm{~m}$ wide, and from $20 \mathrm{~m}$ to $100 \mathrm{~m}$ high. The cave features stalactites and sandbars. The key attraction is provided by a large swimming hole surrounded by a limestone forest. In addition to the scenery, visitors can enjoy different types of activities and local cuisine.

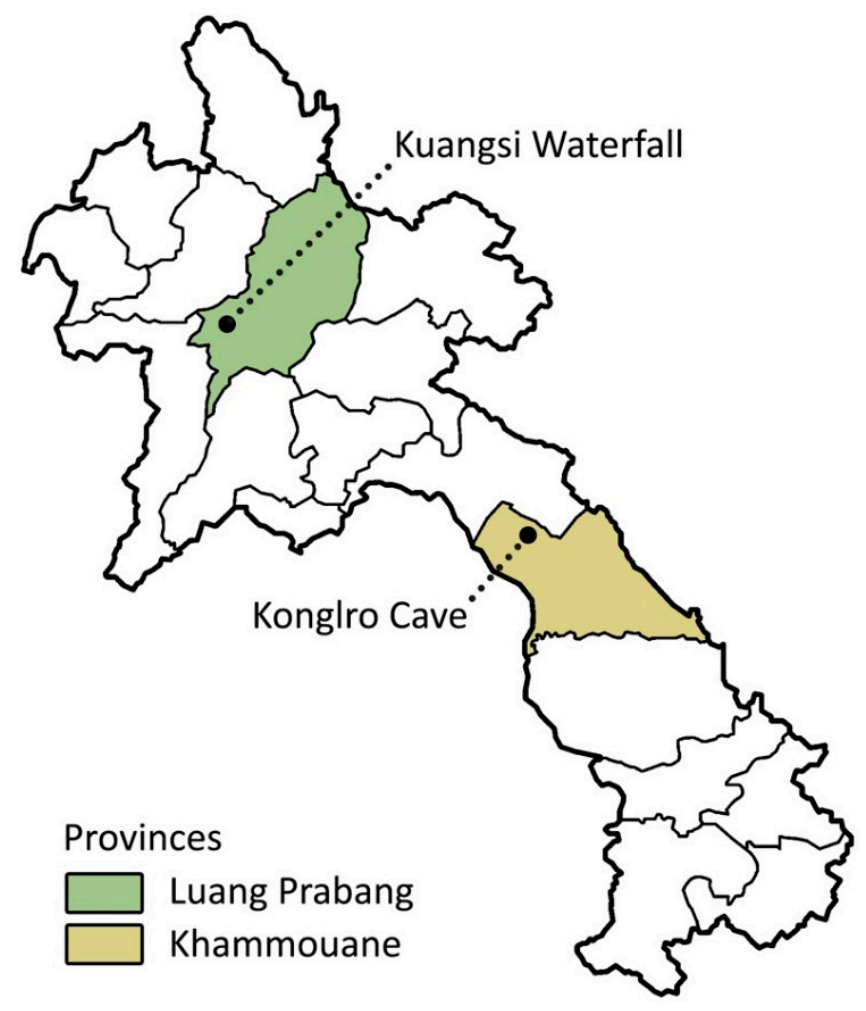

Figure 1. Research sites. 


\subsection{Data Collection}

Data were collected from a sample of visitors to the KSF and KC using self-administered questionnaires. Visitors were selected based on a convenience sampling method. Data collection was carried out by a group of trained assistants from 9:00 a.m. to 5:00 p.m. according to the two parks' opening hours. Respondents answered the questionnaire after they were provided with a brief explanation about the purpose of the study by the assistants. The surveys were conducted at the entrance to the KSF and KC in May, October, and November 2015, including weekdays and weekends. It took approximately $15 \mathrm{~min}$ for respondents to answer all questions. Those who did not respond to all questions were removed from the analysis as the reliability of their responses could not be ascertained. A total of 523 valid questionnaires were obtained at the KSF after 563 questionnaires were distributed (93\% response rate). In the case of KC, a total of 199 valid questionnaires were obtained after 203 questionnaires were distributed ( $98 \%$ response rate).

\subsection{Composition of the Questionnaire}

The questionnaire was composed of 41 items categorized into four sections. The first part (18 questions) asked respondents to rate their motivations to visit the destinations using a five-point Likert scale (Table 1). The specific motivation items were extracted from [17].

Table 1. Tourist motivations (Palacio and McCool [17]).

\begin{tabular}{|c|c|c|c|}
\hline Escape & Healthy Activities & Learning about Nature & Cohesion \\
\hline $\begin{array}{l}\text { - } \quad \text { For the solitude } \\
\text { My mind could move at } \\
\text { a slower pace } \\
\text { Get away from } \\
\text { other people } \\
\text { - } \begin{array}{l}\text { Experience } \\
\text { the tranquility }\end{array}\end{array}$ & $\begin{array}{l}\text { - Help keep me in shape } \\
\text { - Improve my physical health } \\
\text { - Develop my skills and ability } \\
\text { - I could do something } \\
\text { - } \quad \text { I thoughe such as photography } \\
\text { a challenge }\end{array}$ & $\begin{array}{l}\text { - } \quad \text { Be in a natural setting } \\
\text { - } \quad \text { Observe the scenic beauty } \\
\text { ofjoy the noise and smell } \\
\text { - } \quad \text { Understand the natural } \\
\text { - } \quad \text { Learld better } \\
\text { - The adventure }\end{array}$ & $\begin{array}{l}\text { - I could do things with } \\
\text { my companion } \\
\text { - } \quad \text { I could be with friends } \\
\text { - To be with others who } \\
\text { enjoy the same }\end{array}$ \\
\hline
\end{tabular}

The second part (14 statements) measured visitors' attitudes toward aspects of responsible tourist behavior (Table 2). Respondents were asked to indicate their agreement on a five-point Likert scale. This attitudes scale was adopted from [47].

Table 2. Attitudes toward responsible behavior (Kang and Moscardo [47]).

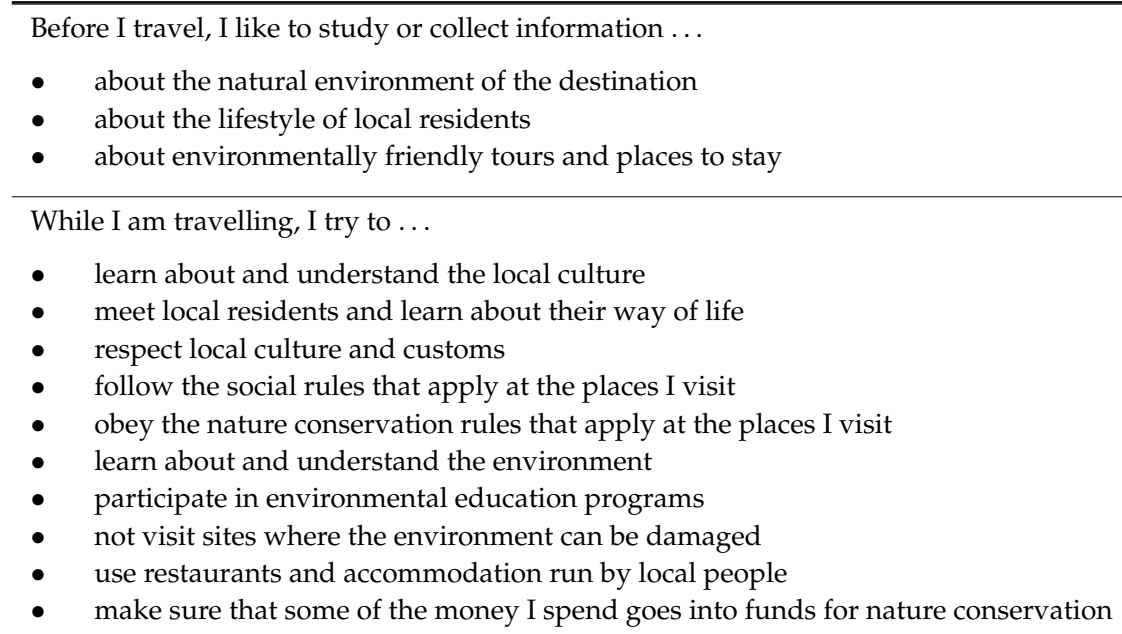

The third part (four items) measured travel-related characteristics, such as visitors' duration of stay at the site, party types, party sizes, and expenditure for local meals. The party type item was divided 
into six categories. Among them, the "package tours" visitors were classified as such if they were part of a package tour, even if they traveled with their family or a partner. This was important in order to differentiate between organized and independent type of visitors. The last part (five items) is related to sociodemographic characteristics such as age, sex, nationality, education level, and occupation.

The questionnaire was translated by professional translators into six languages (English, Korean, Chinese, Japanese, Thai, and Lao), and the translations were then reviewed by native tourism researchers from each country. The selection of languages was based on the data of the most numerous visitors to Lao PDR [4]. It should be recognized, as a limitation, that there was a very small number of visitors from Vietnam, Malaysia, and Indonesia who could not complete the survey due to the lack of translation into their mother language. Finally, it was assumed that European visitors could understand the questions provided in English.

\subsection{Analysis}

Exploratory factor analysis was conducted to verify the validity of the motivation items. Respondents' scores on motivation items were subjected to a principal component analysis followed by a Varimax orthogonal rotation, yielding four major motivation factors, based on [17]. Variables that had an Eigenvalue under 1.0 and a factor loading under 0.5 were eliminated. Reliability analysis (Cronbach's alpha) was then computed to confirm the internal consistency of the items with each dimension. Six of the eighteen items were eliminated through this process. Subsequently, motivation-based non-hierarchical k-means cluster analysis was performed; the averages of the 14 attitudes items were used with motivation items to perform motivation-attitude-based non-hierarchical k-means cluster analysis. As the results of both motivation-based and motivation-attitude-based cluster analysis, four clusters were accepted respectively as the most appropriate way in which to differentiate the sample. To confirm that the clusters were significantly different, the one-way analysis of variance (ANOVA) test was also employed. Finally, the two segmentation solutions named motivation-based segmentation and motivation-attitude-based segmentation were compared in terms of socio-demographic and trip-related variables. ANOVA and Chi-square test were used for the comparison.

\section{Results}

Four factors were extracted from the factor analysis: (a) health, (b) nature, (c) cohesion, and (d) escape. Table 3 shows the loading values of the motivation items. The four factor dimensions explained $65 \%$ of the total variance. Among them, health emerged as the most important motivation factor ( $23 \%$ of the total variance) and cohesion was the least important one $(12 \%)$.

Table 3. Loading values of the motivation items.

\begin{tabular}{|c|c|c|c|c|}
\hline \multirow{2}{*}{ Item } & \multicolumn{4}{|c|}{ Factor } \\
\hline & Health & Nature & Cohesion & Escape \\
\hline Improve my physical health & 0.84 & & & \\
\hline Help keep me in shape & 0.76 & & & \\
\hline Develop my skills and ability & 0.75 & & & \\
\hline I thought it would be a challenge & 0.69 & & & \\
\hline Observe the scenic beauty & & 0.85 & & \\
\hline Be in a natural setting & & 0.74 & & \\
\hline Enjoy the sound and smell of nature & & 0.71 & & \\
\hline Learn more about nature & & 0.54 & & \\
\hline I could do things with my companion & & & 0.87 & \\
\hline I could be with friends/family & & & 0.78 & \\
\hline For the solitude & & & & 0.78 \\
\hline Get away from other people & & & & 0.78 \\
\hline Eigenvalue & 2.77 & 2.13 & 1.50 & 1.38 \\
\hline Proportion of variance & 0.23 & 0.18 & 0.12 & 0.12 \\
\hline Cronbach's alpha & 0.79 & 0.72 & - & - \\
\hline
\end{tabular}


The four motivations identified in Table 1 were subjected to non-hierarchical cluster analysis, producing the results in Table 3. As shown in Table 4, the four clusters were labeled as "Nature and Cohesion-Seeking Tourists (Segment A)," "Nature-Seeking Tourists (Segment B)," "Passive Nature-Seeking Tourists (Segment C)," and "Want-It-All Tourists (Segment D)." Segment A (30\% of the sample) scored high on both "nature" and "cohesion." Segment B (13\% of the sample) scored high on only "nature." Segment C ( $21 \%$ of the sample) showed low scores on every aspect, but within the segment, it showed relatively high scores on "nature." By contrast, Segment D (36\% of the sample) scored high on all motivation factors.

Table 4. Motivation-based segmentation.

\begin{tabular}{|c|c|c|c|c|c|}
\hline \multirow[b]{2}{*}{ Factor } & \multicolumn{4}{|c|}{ Segment } & \multirow[b]{2}{*}{ F-Value } \\
\hline & $\begin{array}{c}\text { A } \\
N=214\end{array}$ & $\begin{array}{c}\text { B } \\
N=97\end{array}$ & $\begin{array}{c}\mathrm{C} \\
N=149\end{array}$ & $\begin{array}{c}\mathrm{D} \\
N=262\end{array}$ & \\
\hline Health & 3.31 & 1.94 & 2.60 & 4.04 & $96.12^{* * *}$ \\
\hline Nature & 4.33 & 4.01 & 3.89 & 4.57 & $12.9^{* * *}$ \\
\hline Escape & 2.94 & 1.92 & 3.00 & 4.32 & $370.5^{* * *}$ \\
\hline Cohesion & 4.13 & 3.85 & 2.09 & 4.22 & $2.92 *$ \\
\hline Labels & $\begin{array}{c}\text { Nature-Cohesion-Seeking } \\
\text { Tourists }\end{array}$ & $\begin{array}{l}\text { Nature-Seeking } \\
\text { Tourists }\end{array}$ & $\begin{array}{c}\text { Passive Nature-Seeking } \\
\text { Tourists }\end{array}$ & $\begin{array}{l}\text { Want-It-All } \\
\text { Tourists }\end{array}$ & \\
\hline
\end{tabular}

Table 5 presents the results of motivation and responsible attitudes-based segmentation. The four clusters were labeled as "Want-It-All Responsible Tourists (Segment A)," "Nature and Cohesion-Seeking Tourists (Segment B)," "Passive Nature-Seeking Tourists (Segment C)," and "Nature-Seeking Tourists (Segment D)." Segment A (33\% of the sample) scored high on every motivation aspect. Segment B ( $25 \%$ of the sample) scored high on "nature" and "cohesion." Segment C ( $16 \%$ of the sample) showed low scores on every motivation aspect, but within the segment, it showed relatively high scores on "nature." Segment D ( $26 \%$ of the sample) scored high on "nature." Among the segments, Segment A scored the highest on "responsible attitudes".

Table 5. Motivation-attitude-based segmentation.

\begin{tabular}{|c|c|c|c|c|c|}
\hline \multirow[b]{2}{*}{ Factor } & \multicolumn{4}{|c|}{ Segment } & \multirow[b]{2}{*}{ F-Value } \\
\hline & $\begin{array}{c}\mathrm{A} \\
N=238\end{array}$ & $\begin{array}{c}\text { B } \\
N=182\end{array}$ & $\begin{array}{c}\mathrm{C} \\
N=115\end{array}$ & $\begin{array}{c}\text { D } \\
N=187\end{array}$ & \\
\hline Health & 4.16 & 2.69 & 2.20 & 3.24 & $137 * * *$ \\
\hline Nature & 4.63 & 4.23 & 3.85 & 4.14 & $83.3^{* * *}$ \\
\hline Escape & 4.15 & 2.30 & 2.43 & 3.78 & $14.39^{* * *}$ \\
\hline Cohesion & 4.83 & 4.27 & 1.99 & 3.22 & $431.2^{* * *}$ \\
\hline $\begin{array}{l}\text { Responsible } \\
\text { Attitudes }\end{array}$ & 4.45 & 4.36 & 4.27 & 4.04 & $68.84^{* * *}$ \\
\hline Labels & $\begin{array}{c}\text { Want-It-All } \\
\text { Responsible Tourists }\end{array}$ & $\begin{array}{c}\text { Nature and } \\
\text { Cohesion-seeking } \\
\text { Tourists }\end{array}$ & $\begin{array}{c}\text { Passive } \\
\text { Nature-Seeking } \\
\text { Tourists }\end{array}$ & $\begin{array}{c}\text { Nature-Seeking } \\
\text { Tourists }\end{array}$ & \\
\hline
\end{tabular}

*** $p<0.001$

The two types of segmentations were described in terms of demographic variables. The results of these comparisons can be found in Tables 6 and 7. It is important to note that these tables show the strength of F- and Chi-square test scores. When the demographic profiles of the two different segmentation types were compared, there were more statistical differences among motivation-attitude segments than there were among motivation segments, as differences among motivation segments regarding age and genders were non-significant. 
Table 6. Sociodemographic characteristics of motivation segments.

\begin{tabular}{|c|c|c|c|c|c|c|}
\hline Variable & Total & $\begin{array}{c}\text { Nature and } \\
\text { Cohesion-Seeking } \\
\text { Tourists } \\
\end{array}$ & $\begin{array}{c}\text { Nature-Seeking } \\
\text { Tourists }\end{array}$ & $\begin{array}{c}\text { Passive } \\
\text { Nature-Seeking } \\
\text { Tourists } \\
\end{array}$ & $\begin{array}{l}\text { Want-It-All } \\
\text { Tourists }\end{array}$ & $\begin{array}{c}\text { Chi-Square or } \\
\text { F-Ratio }\end{array}$ \\
\hline Avg. age & $\begin{array}{c}N=703 \\
33.9\end{array}$ & $\begin{array}{c}N=210 \\
34.2\end{array}$ & $\begin{array}{c}N=96 \\
36.5\end{array}$ & $\begin{array}{c}N=147 \\
33.1\end{array}$ & $\begin{array}{c}N=250 \\
33.1\end{array}$ & 1.875 \\
\hline $\begin{array}{c}\text { Sex } \\
\text { Male (\%) } \\
\text { Female (\%) }\end{array}$ & $\begin{array}{c}N=716 \\
54.6 \\
45.4\end{array}$ & $\begin{array}{c}N=214 \\
56.5 \\
43.5\end{array}$ & $\begin{array}{c}N=96 \\
44.8 \\
55.2\end{array}$ & $\begin{array}{c}N=147 \\
53.1 \\
46.9\end{array}$ & $\begin{array}{c}N=259 \\
57.5 \\
42.5\end{array}$ & 5.088 \\
\hline $\begin{array}{c}\text { Nationality } \\
\text { Laos }(\%) \\
\text { ASEAN }(\%) \\
\text { Non-ASEAN }(\%) \\
\text { Europe }(\%) \\
\text { North America }(\%) \\
\text { South America }(\%) \\
\text { Other }(\%)\end{array}$ & $\begin{array}{c}N=716 \\
26.4 \\
14.5 \\
23.0 \\
24.3 \\
6.0 \\
1.7 \\
4.1\end{array}$ & $\begin{array}{c}N=213 \\
20.7 \\
13.1 \\
24.4 \\
28.2 \\
5.2 \\
2.8 \\
5.6\end{array}$ & $\begin{array}{c}N=96 \\
6.2 \\
3.1 \\
37.5 \\
39.6 \\
9.4 \\
3.1 \\
1.0\end{array}$ & $\begin{array}{c}N=147 \\
15.6 \\
12.9 \\
21.1 \\
34 \\
7.5 \\
0.7 \\
8.2\end{array}$ & $\begin{array}{c}N=260 \\
44.6 \\
20.8 \\
17.7 \\
10 \\
4.6 \\
0.8 \\
1.5\end{array}$ & $145.227^{* * *}$ \\
\hline $\begin{array}{c}\text { Education } \\
\text { Primary/secondary graduated or less (\%) } \\
\text { In technical/vocational school (\%) } \\
\text { Technical/vocational school graduated (\%) } \\
\text { In college/university (\%) } \\
\text { College/university graduated (\%) } \\
\text { Master's degree or higher degree (\%) }\end{array}$ & $\begin{array}{c}N=706 \\
7.9 \\
15.4 \\
34.7 \\
14.3 \\
17.3 \\
10.3\end{array}$ & $\begin{array}{c}N=207 \\
6.8 \\
17.4 \\
33.8 \\
13.0 \\
21.3 \\
7.7\end{array}$ & $\begin{array}{l}N=96 \\
10.4 \\
11.5 \\
22.9 \\
16.7 \\
26.0 \\
12.5\end{array}$ & $\begin{array}{c}N=147 \\
7.5 \\
16.3 \\
30.6 \\
19.0 \\
12.2 \\
14.3\end{array}$ & $\begin{array}{c}N=256 \\
8.2 \\
14.8 \\
42.2 \\
11.7 \\
13.7 \\
9.4\end{array}$ & $30.124^{*}$ \\
\hline $\begin{array}{c}\text { Occupation } \\
\text { Government }(\%) \\
\text { Private company (\%) } \\
\text { Student }(\%) \\
\text { Housewife }(\%) \\
\text { Retired }(\%) \\
\text { Self-employed }(\%) \\
\text { Others }(\%)\end{array}$ & $\begin{array}{c}N=700 \\
36.6 \\
19.4 \\
18.3 \\
10.9 \\
4.4 \\
4.1 \\
6.3\end{array}$ & $\begin{array}{c}N=208 \\
36.1 \\
24.5 \\
14.9 \\
9.1 \\
3.4 \\
4.3 \\
7.7\end{array}$ & $\begin{array}{c}N=96 \\
21.9 \\
25.0 \\
14.6 \\
14.6 \\
7.3 \\
5.2 \\
11.5\end{array}$ & $\begin{array}{c}N=143 \\
30.1 \\
23.1 \\
17.5 \\
13.3 \\
3.5 \\
3.5 \\
9.1\end{array}$ & $\begin{array}{c}N=253 \\
46.2 \\
11.1 \\
22.9 \\
9.5 \\
4.7 \\
4.0 \\
1.6\end{array}$ & $54.795^{* * *}$ \\
\hline
\end{tabular}


Table 7. Socio-demographic characteristics of motivation-attitude segments.

\begin{tabular}{|c|c|c|c|c|c|c|}
\hline Variable & Total & $\begin{array}{c}\text { Want-It-All } \\
\text { Responsible Tourists }\end{array}$ & $\begin{array}{c}\text { Nature and } \\
\text { Cohesion-Seeking } \\
\text { Tourists } \\
\end{array}$ & $\begin{array}{c}\text { Passive } \\
\text { Nature-Seeking } \\
\text { Tourists } \\
\end{array}$ & $\begin{array}{l}\text { Nature-Seeking } \\
\text { Tourists }\end{array}$ & $\begin{array}{c}\text { Chi-Square or } \\
\text { F-Ratio }\end{array}$ \\
\hline Avg. age & $\begin{array}{c}N=703 \\
33.9\end{array}$ & $\begin{array}{c}N=229 \\
34.8\end{array}$ & $\begin{array}{c}N=179 \\
35.0\end{array}$ & $\begin{array}{c}N=112 \\
33.7\end{array}$ & $\begin{array}{c}N=183 \\
31.7\end{array}$ & $6.216^{*}$ \\
\hline $\begin{array}{c}\text { Sex } \\
\text { Male }(\%) \\
\text { Female }(\%)\end{array}$ & $\begin{array}{c}N=716 \\
54.6 \\
45.4\end{array}$ & $\begin{array}{c}N=236 \\
59.3 \\
40.7\end{array}$ & $\begin{array}{c}N=182 \\
46.2 \\
53.8\end{array}$ & $\begin{array}{c}N=112 \\
54.5 \\
45.5\end{array}$ & $\begin{array}{c}N=186 \\
57.0 \\
43.0\end{array}$ & 7.790 * \\
\hline $\begin{array}{c}\text { Nationality } \\
\text { Laos }(\%) \\
\text { ASEAN }(\%) \\
\text { Non-ASEAN }(\%) \\
\text { Europe }(\%) \\
\text { North America }(\%) \\
\text { South America }(\%) \\
\text { Other }(\%)\end{array}$ & $\begin{array}{c}N=716 \\
26.4 \\
14.5 \\
23.0 \\
24.3 \\
6.0 \\
1.7 \\
4.1\end{array}$ & $\begin{array}{c}N=236 \\
40.7 \\
21.2 \\
18.2 \\
12.3 \\
5.1 \\
0.0 \\
2.5\end{array}$ & $\begin{array}{c}N=282 \\
12.7 \\
6.1 \\
30.9 \\
34.8 \\
7.7 \\
4.4 \\
3.3\end{array}$ & $\begin{array}{c}N=223 \\
9.8 \\
7.1 \\
25.9 \\
40.2 \\
7.1 \\
0.9 \\
8.9\end{array}$ & $\begin{array}{c}N=287 \\
31.6 \\
18.7 \\
19.8 \\
19.8 \\
4.8 \\
1.6 \\
3.7\end{array}$ & $133.758^{* * *}$ \\
\hline $\begin{array}{c}\text { Education } \\
\text { Primary/secondary graduated or less (\%) } \\
\text { In technical/vocational school (\%) } \\
\text { Technical/vocational school graduated (\%) } \\
\text { In college/university (\%) } \\
\text { College/university graduated (\%) } \\
\text { Master's degree or higher degree (\%) }\end{array}$ & $\begin{array}{c}N=706 \\
7.9 \\
15.4 \\
34.7 \\
14.3 \\
17.3 \\
10.3\end{array}$ & $\begin{array}{c}N=231 \\
9.1 \\
14.3 \\
41.1 \\
11.7 \\
14.7 \\
9.1\end{array}$ & $\begin{array}{c}N=179 \\
10.1 \\
15.6 \\
27.4 \\
13.4 \\
21.8 \\
11.7\end{array}$ & $\begin{array}{c}N=112 \\
4.5 \\
14.3 \\
32.1 \\
23.2 \\
11.6 \\
14.3\end{array}$ & $\begin{array}{c}N=184 \\
6.5 \\
17.4 \\
35.3 \\
13.0 \\
19.6 \\
8.2\end{array}$ & $26.542 *$ \\
\hline $\begin{array}{c}\text { Occupation } \\
\text { Government (\%) } \\
\text { Private company (\%) } \\
\text { Student }(\%) \\
\text { Housewife }(\%) \\
\text { Retired }(\%) \\
\text { Self-employed (\%) } \\
\text { Others (\%) }\end{array}$ & $\begin{array}{c}N=700 \\
36.6 \\
19.4 \\
18.3 \\
10.9 \\
4.4 \\
4.1 \\
6.3\end{array}$ & $\begin{array}{c}N=231 \\
47.6 \\
11.7 \\
19.5 \\
10.4 \\
4.8 \\
3.9 \\
2.2\end{array}$ & $\begin{array}{c}N=178 \\
27.5 \\
24.7 \\
18.0 \\
10.7 \\
3.4 \\
4.5 \\
11.2\end{array}$ & $\begin{array}{c}N=108 \\
31.5 \\
18.5 \\
15.7 \\
17.6 \\
6.5 \\
1.9 \\
8.3\end{array}$ & $\begin{array}{c}N=183 \\
34.4 \\
24.6 \\
18.6 \\
7.7 \\
3.8 \\
5.5 \\
5.5\end{array}$ & $49.818^{* * *}$ \\
\hline
\end{tabular}


Table 8. Trip-related characteristics of motivation segments.

\begin{tabular}{|c|c|c|c|c|c|c|}
\hline Variable & Total & $\begin{array}{c}\text { Nature and } \\
\text { Cohesion-Seeking } \\
\text { Tourists }\end{array}$ & $\begin{array}{c}\text { Nature-Seeking } \\
\text { Tourists }\end{array}$ & $\begin{array}{c}\text { Passive } \\
\text { Nature-Seeking } \\
\text { Tourists }\end{array}$ & $\begin{array}{l}\text { Want-It-All } \\
\text { Tourists }\end{array}$ & $\begin{array}{l}\text { Chi-Square or } \\
\text { F-Ratio }\end{array}$ \\
\hline Stay at the study site & $N=703$ & $N=205$ & $N=97$ & $N=146$ & $N=255$ & 8.192 \\
\hline $3 \mathrm{~h}$ or less $(\%)$ & 57.3 & 54.6 & 66.0 & 56.8 & 56.5 & \\
\hline $3-6 \mathrm{~h}(\%)$ & 34.3 & 37.1 & 26.8 & 37.0 & 33.3 & \\
\hline More than $6 \mathrm{~h}(\%)$ & 5.0 & 4.4 & 4.1 & 2.7 & 7.1 & \\
\hline 2 days or more (\%) & 3.4 & 3.9 & 3.1 & 3.4 & 3.1 & \\
\hline Type of companion & $N=712$ & $N=211$ & $N=96$ & $N=146$ & $N=259$ & $107.740^{* * *}$ \\
\hline Alone $(\%)$ & 8.6 & 5.2 & 1.0 & 24.7 & 5.0 & \\
\hline Spouse/partner (\%) & 18.3 & 22.7 & 19.8 & 18.5 & 13.9 & \\
\hline Family with children (\%) & 44.0 & 42.7 & 33.3 & 31.5 & 56.0 & \\
\hline Relatives/friends (\%) & 13.5 & 15.2 & 25.0 & 11.0 & 9.3 & \\
\hline Group (\%) & 4.6 & 6.2 & 6.2 & 6.8 & 1.5 & \\
\hline Package tour $(\%)$ & 11.1 & 8.1 & 14.6 & 7.5 & 14.3 & \\
\hline \multirow[t]{2}{*}{ Avg. no. of persons per party } & $N=697$ & $N=205$ & $N=96$ & $N=142$ & $N=254$ & \\
\hline & 11.9 & 10.5 & 7.9 & 6.5 & 17.7 & $5.851 *$ \\
\hline $\begin{array}{c}\text { Avg. expenditure per day per } \\
\text { person }\end{array}$ & $N=601$ & $N=182$ & $N=86$ & $N=122$ & $N=211$ & \\
\hline Meals & $\$ 8.6$ & $\$ 8.4$ & $\$ 6.9$ & $\$ 7.6$ & $\$ 10.0$ & $4.841 *$ \\
\hline
\end{tabular}

${ }^{*} p<0.05 ;{ }^{* *} p<0.01 ;{ }^{* * *} p<0.001$ 
Table 9. Trip-related characteristics of motivation-attitude segments.

\begin{tabular}{|c|c|c|c|c|c|c|}
\hline Variable & Total & $\begin{array}{c}\text { Want-It-All } \\
\text { Responsible Tourists }\end{array}$ & $\begin{array}{c}\text { Nature and } \\
\text { Cohesion-Seeking } \\
\text { Tourists }\end{array}$ & $\begin{array}{c}\text { Passive } \\
\text { Nature-Seeking } \\
\text { Tourists }\end{array}$ & $\begin{array}{c}\text { Nature-Seeking } \\
\text { Tourists }\end{array}$ & $\begin{array}{c}\text { Chi-Square or } \\
\text { F-Ratio }\end{array}$ \\
\hline Stay at the study site & $N=703$ & $N=233$ & $N=177$ & $N=115$ & $N=178$ & 17.737 * \\
\hline 3-6 h (\%) & 34.3 & 30.9 & 32.8 & 33.0 & 41.0 & \\
\hline More than $6 \mathrm{~h}(\%)$ & 5.0 & 8.6 & 3.4 & 2.6 & 3.4 & \\
\hline 2 days or more $(\%)$ & 3.4 & 4.3 & 1.7 & 2.6 & 4.5 & \\
\hline Type of companion & $N=712$ & $N=236$ & $N=180$ & $N=113$ & $N=183$ & $84.596^{* * *}$ \\
\hline Spouse/partner (\%) & 18.3 & 16.1 & 22.2 & 18.6 & 16.9 & \\
\hline Family with children (\%) & 44.0 & 55.1 & 37.8 & 29.2 & 44.8 & \\
\hline Relatives/friends (\%) & 13.5 & 9.3 & 18.9 & 11.5 & 14.8 & \\
\hline Group $(\%)$ & 4.6 & 2.1 & 7.2 & 6.2 & 4.4 & \\
\hline Package tour (\%) & 11.1 & 13.6 & 11.1 & 8.8 & 9.3 & \\
\hline \multirow[t]{2}{*}{ Avg. no. of persons per party } & $N=697$ & $N=299$ & $N=181$ & $N=111$ & $N=176$ & \\
\hline & 11.9 & 18.0 & 7.9 & 5.6 & 12.1 & $4.402 *$ \\
\hline $\begin{array}{c}\text { Avg. expenditure per day per } \\
\text { person }\end{array}$ & $N=601$ & $N=193$ & $N=160$ & $N=97$ & $N=151$ & \\
\hline Meals & $\$ 8.6$ & $\$ 10.5$ & $\$ 7.5$ & $\$ 6.7$ & $\$ 8.5$ & $7.148^{* *}$ \\
\hline
\end{tabular}


The two types of segmentations were also described in terms of trip-related variables. The results of these comparisons can be found in Tables 8 and 9. These two tables also show the strength of Fand Chi-square test scores. As presented in the two tables, there were more statistical differences among motivation-attitude segments than there were among motivation segments. For instance, motivation-attitude segments differed from each other statistically in every trip-related aspect, while motivation segments were not significantly different in terms of visitors' staying time at the destination. Furthermore, in terms of visitors' average expenditure for meals, motivation-attitude segmentation solution showed higher significant differences than motivation segmentation as the former's $p$-values were lower than 0.01 , while the latter's $p$-values were lower than 0.05 but higher than 0.01 .

\section{Discussion and Conclusions}

The motivation-based cluster analysis generated four distinctive segments labelled as "Nature and Cohesion-Seeking Tourists", "Nature-Seeking Tourists", "Passive Nature-Seeking Tourists", and "Want-It-All Tourists". This result concurs with those of earlier studies in two ways. Firstly, every segment showed "nature" as a common motivation. This is in close agreement with the results of numerous investigators (e.g., $[17,21,22]$ ) who have explored travel motivation of visitors to nature-based tourism destinations. Secondly, although all four segments showed relatively high scores on "nature", they had significantly different scores on other motivation factors. This result is in line with those of previous studies claiming that motivation-based segmentation is useful in identifying different tourist groups' needs and desires [10].

In a similar vein, the motivation-attitude-based cluster analysis also generated four significantly distinctive segments labelled as "Want-It-All Responsible Tourists", "Nature and Cohesion-Seeking Tourists", "Passive Nature-Seeking Tourists", and "Nature-Seeking Tourists". This result indicates that along with motivation, responsible attitudes is also a viable option for segmenting tourists. Because the motivation-attitude-based segmentation identifies responsible tourists as well as their desires, it provides destination managers with more information about tourists than motivation-based segmentation studies alone. Although there are several studies advocating for either the motivation or the attitude-based approach, there is relatively little research on mixed methods involving both approaches. Furthermore, similar recent studies have employed only environmentally-responsible attitudes when segmenting tourists [24,25,32,34-43]. This study, however, also included attitudes about sociocultural and economic responsibility toward the local community. As many tourism areas in Lao PDR feature outstanding environmental conditions in a culturally and economically sensitive setting, destination managers require visitors' responsible behavior regarding not only environmental, but also sociocultural and economic aspects.

In order to provide destination managers with valuable information, segments need to be sufficiently distinguishable from each other by socio-demographic and trip-related characteristics [23]. For these reasons, this study compared segment heterogeneity between motivation-based and motivation-attitude-based segmentation by exploring these differences. The result of this study indicates the superiority of motivation-attitude-based segmentation over motivation-based segmentation in separating segments. Specifically, the results presented in Tables 6-9 show that motivation-attitude-based segmentation produces more distinctive segments than motivation-based segmentation in terms of socio-demographic and trip-related characteristics. For example, motivation-attitude-based segments were statistically different in every socio-demographic aspect, while motivation-based segments were not significantly different in age and gender categories. Furthermore, motivation-attitude-based segments significantly differed from each other in every trip-related aspect, while motivation-based segments did not show a significant difference in visitors' duration of stay at the destination. In addition, in terms of visitors' average expenditure for meals, motivation-attitude-based segmentation produced more highly significant results than motivation-based segmentation. These results indicate that motivation-attitude-based segmentation is superior to motivation-based segmentation, with respect to distinguishing different segments. This 
result contributes to the body of research on comparison of segmentation techniques, which has been regarded as an important topic, although rarely investigated [23].

The results of this study also have managerial implications. In particular, knowledge about the characteristics of "responsible" tourist markets, which feature relatively high levels of responsible attitudes, can be applied for selective marketing strategies by destination managers $[5,6]$. Scheyvens [50] noted that small groups of independent travelers or backpackers can provide a significant income to local people in remote areas, because other types of visitors simply avoid such destinations. However, although the economic benefits provided by different tourism segments are vital, visitors' responsible behavior is equally important, especially for small destinations in developing countries that can be easily affected by the environmental and sociocultural aspects of tourism. As noted by Egmond [51], positive economic impacts do not always go hand-in-hand with positive social and cultural impacts. The negative perception of hosts toward their guests increases with an increase in the number of visitors and related impacts, causing irritation [52]. This can be minimized to a certain degree by the types of visitors who cause low negative environmental and sociocultural impacts, bringing economic benefits to local people. A noticeable improvement of quality of life in the community regarding health, education, and economy is one of the conditions that supports tourism [53]. If the benefits from tourism are not clearly visible and felt, it loses community support because the negative impacts outweigh the benefits, which is usually a serious obstacle to tourism development [54], and in some cases, can cause the decline of the destination [55]. This study, therefore, looked for visitors who are concerned with sustaining and enhancing the local culture and heritage through their travels and, who, at the same time, bring positive economic benefits to local people.

The "Want-It-All Responsible Tourists" segment in this study can be recommended as the most "desirable" market. It is important to note that "Want-It-All Responsible Tourists" were different from the others in terms of their highest level of expenditure for local meals, while still scoring high on social responsibility. Several studies have argued that heavy spenders benefit tourist areas and have suggested ways to encourage them to visit more often [56-58]. In order to attract them to destinations, several managerial practices can be implemented. With the highest ratio of package tour visitors (average party size is 18.0) among the segments and the largest ratio of ASEAN and national tourists, the "Want-It-All Responsible Tourists" market can be targeted by local tour operators and travel agencies in the country or neighboring ASEAN countries. The recent entrance of Lao PDR into the ASEAN Economic Community (AEC), and the consequent planned development of a regional tourism destination [59], has given rise to the possibility of establishing cooperation with specific outbound operators who prepare their customers for visiting sensitive destinations. Indeed, inappropriate and limited communication and promotion activities are the main reasons for visitors not adopting responsible tourism practices [45]. Communication activities are necessary to sensitize tourists to perceive and understand fully the effects of their behavior on the host destination so that they can adopt more responsible behavior [48]. In this context, interpretation services might play a crucial role in acquiring environmental and social knowledge necessary to perform positive behaviors [60].

"Want-It-All Responsible Tourists", with a relatively large proportion of ASEAN tourists, showed a high level of responsible attitudes, as well as relatively high expenditure. Indeed, little academic attention has been paid to the characteristics of ASEAN tourist markets. With high spending and responsible attitudes toward the environmental, sociocultural, and economic aspects of a destination, this group has the highest potential to be the most "desirable" sustainable tourists. Further research should be conducted to determine whether there are significant differences in tourists' characteristics among neighboring ASEAN countries. In addition, to formulate more effective management plans and marketing strategies, more information is needed. For example, in order to fully understand which particular group is the most beneficial to the region in terms of spending and responsible behavior, further investigation of expenditure patterns and capital inflows into local communities, as well as sociocultural impacts is required. Although this study attempted to determine visitors' 
expenditure on local meals, in future research, more specific items of expenditure, such as spending on accommodations, souvenirs, and activities, can be included in the survey.

Author Contributions: Conceptualization, Y.J., S.Z. and S.-i.K.; Methodology, Y.J.; Software, Y.J.; Validation, Y.J., S.Z., and S.-i.K.; Formal Analysis, Y.J.; Investigation, Y.J. and J.-s.C.; Resources, J.-s.C.; Data Curation, Y.J.; Writing-Original Draft Preparation, Y.J. and S.Z.; Writing-Review and Editing, S.-i.K.; Visualization, Y.J.; Supervision, S.-i.K.; Project Administration, S.-i.K. and J.-s.C.; Funding Acquisition, S.-i.K.

Funding: This research received no external funding.

Conflicts of Interest: The authors declare no conflict of interest.

\section{References}

1. Wong, E.P.Y.; Mistilis, N.; Dwyer, L. Understanding asean tourism collaboration-The preconditions and policy framework formulation. Int. J. Tour. Res. 2010, 12, 291-302. [CrossRef]

2. Lao National Tourism Administration. Lao PDR Tourism Strategy 2006-2020; LNTA: Vientiane, Lao, 2006.

3. Suntikul, W.; Bauer, T.; Song, H. Pro-poor tourism development in Viengxay, Laos: Current state and future prospects. Asia Pac. J. Tour. Res. 2009, 14, 153-168. [CrossRef]

4. Ministry of Information Culture and Tourism. 2016 Statistical Report on Tourism in Laos; Ministry of Information Culture and Tourism: Vientiane, Lao, 12 June 2017; pp. 1-35.

5. Dolnicar, S.; Leisch, F. Selective marketing for environmentally sustainable tourism. Tour. Manag. 2008, 29, 672-680. [CrossRef]

6. Stoeckl, N.; Greiner, R.; Mayocchi, C. The community impacts of different types of visitors: An empirical investigation of tourism in north-west Queensland. Tour. Manag. 2006, 27, 97-112. [CrossRef]

7. Puhakka, R. Environmental concern and responsibility among nature tourists in Oulanka Pan Park, Finland. Scand. J. Hosp. Tour. 2011, 11, 76-96. [CrossRef]

8. Jang, S.C.; Morrison, A.M.; O'Leary, J.T. Benefit segmentation of Japanese pleasure travelers to the USA and Canada: Selecting target markets based on the profitability and risk of individual market segments. Tour. Manag. 2002, 23, 367-378. [CrossRef]

9. Bigné, E.; Gnoth, J.; Andreu, L. Advanced topics in tourism market segmentation. Tourism Management: Analysis, Behaviour and Strategy. 2008, pp. 151-173. Available online: https:/ /www.cabi.org/cabebooks/ ebook/20083075456 (accessed on 9 October 2018).

10. Albayrak, T.; Caber, M. Examining the relationship between tourist motivation and satisfaction by two competing methods. Tour. Manag. 2018, 69, 201-213. [CrossRef]

11. O'Leary, S.; Deegan, J. Ireland's image as a tourism destination in France: Attribute importance and performance. J. Travel Res. 2005, 43, 247-256. [CrossRef]

12. Bogari, N.B.; Crowther, G.; Marr, N. Motivation for domestic tourism: A case study of the kingdom of Saudi Arabia. Tour. Anal. 2003, 8, 137-141. [CrossRef]

13. Pearce, P.L.; Lee, U.-I. Developing the travel career approach to tourist motivation. J. Travel Res. 2005, 43, 226-237. [CrossRef]

14. Correia, A.; Crouch, G.I. Tourist perceptions of and motivations for visiting the Algarve, portugal. Tour. Anal. 2003, 8, 165-169. [CrossRef]

15. Huang, R.; Sarigöllü, E. Benefit segmentation of tourists to the Caribbean. J. Int. Consum. Mark. 2008, 20, 67-83. [CrossRef]

16. Sarigöllü, E.; Huang, R. Benefits segmentation of visitors to Latin America. J. Travel Res. 2005, 43, $277-293$. [CrossRef]

17. Palacio, V. Identifying ecotourists in Belize through benefit segmentation: A preliminary analysis. J. Sustain. Tour. 1997, 5, 234-243. [CrossRef]

18. Andreu, L.; Kozak, M.; Avci, N.; Cifter, N. Market segmentation by motivations to travel: British tourists visiting turkey. J. Travel Tour. Mark. 2006, 19, 1-14. [CrossRef]

19. Li, M.; Huang, Z.; Cai, L.A. Benefit segmentation of visitors to a rural community-based festival. J. Travel Tour. Mark. 2009, 26, 585-598. [CrossRef]

20. Rid, W.; Ezeuduji, I.O.; Pröbstl-Haider, U. Segmentation by motivation for rural tourism activities in the Gambia. Tour. Manag. 2014, 40, 102-116. [CrossRef] 
21. Hultman, M.; Kazeminia, A.; Ghasemi, V. Intention to visit and willingness to pay premium for ecotourism: The impact of attitude, materialism, and motivation. J. Bus. Res. 2015, 68, 1854-1861. [CrossRef]

22. Kim Lian Chan, J.; Baum, T. Motivation factors of ecotourists in ecolodge accommodation: The push and pull factors. Asia Pac. J. Tour. Res. 2007, 12, 349-364. [CrossRef]

23. Pesonen, J.A. Targeting rural tourists in the internet: Comparing travel motivation and activity-based segments. J. Travel Tour. Mark. 2015, 32, 211-226. [CrossRef]

24. Formica, S.; Uysal, M. Segmentation of travelers based on environmental attitudes. J. Hosp. Leis. Mark. 2001, 9, 35-49. [CrossRef]

25. Fairweather, J.R.; Maslin, C.; Simmons, D.G. Environmental values and response to ecolabels among international visitors to New Zealand. J. Sustain. Tour. 2005, 13, 82-98. [CrossRef]

26. Marques, C.; Reis, E.; Menezes, J. Profiling the segments of visitors to Portuguese protected areas. J. Sustain. Tour. 2010, 18, 971-996. [CrossRef]

27. Mody, M.; Day, J.; Sydnor, S.; Jaffe, W.; Lehto, X. The different shades of responsibility: Examining domestic and international travelers' motivations for responsible tourism in India. Tour. Manag. Perspect. 2014, 12, 113-124. [CrossRef]

28. Holden, A. In need of new environmental ethics for tourism? Ann. Tour. Res. 2003, 30, 94-108. [CrossRef]

29. Lovelock, B.; Lovelock, K. The Ethics of Tourism: Critical and Applied Perspectives; Routledge: Abingdon, UK, 2013.

30. Bowles, L.; Ruhanen, L. Disseminating environmental ethics and values: A study of ecotourism business owners. Tour. Rev. 2018, 73, 252-261. [CrossRef]

31. Ajzen, I.; Driver, B.L. Application of the theory of planned behavior to leisure choice. J. Leis. Res. 1992, 24, 207-224. [CrossRef]

32. Kim, A.K.; Weiler, B. Visitors' attitudes towards responsible fossil collecting behaviour: An environmental attitude-based segmentation approach. Tour. Manag. 2013, 36, 602-612. [CrossRef]

33. Dunlap, R.E.; Van Liere, K.D. The "new environmental paradigm". J. Environ. Educ. 1978, 9, 10-19. [CrossRef]

34. Higham, J.; Carr, A.; Gale, S. Ecotourism in New Zealand: Profiling Visitors to New Zealand Ecotourism; Department of Tourism, University of Otago: Dunedin, New Zealand, 2001.

35. Zografos, C.; Allcroft, D. The environmental values of potential ecotourists: A segmentation study. J. Sustain. Tour. 2007, 15, 44-66. [CrossRef]

36. Weaver, D.B.; Lawton, L.J. Visitor attitudes toward tourism development and product integration in an Australian urban-rural fringe. J. Travel Res. 2004, 42, 286-296. [CrossRef]

37. Ballantyne, R.; Packer, J.; Hughes, K. Tourists' support for conservation messages and sustainable management practices in wildlife tourism experiences. Tour. Manag. 2009, 30, 658-664. [CrossRef]

38. Wang, C.-P.; Li, C.; Liu, S.-T. A multidimensional environmental value orientation approach to forest recreation area tourism market segmentation. Forests 2016, 7, 92. [CrossRef]

39. Castellanos-Verdugo, M.; Vega-Vázquez, M.; Oviedo-García, M.Á.; Orgaz-Agüera, F. The relevance of psychological factors in the ecotourist experience satisfaction through ecotourist site perceived value. J. Clean. Prod. 2016, 124, 226-235. [CrossRef]

40. Kim, A.K. Determinants of tourist behaviour in coastal environmental protection. Tour. Geogr. 2012, 14, 26-49. [CrossRef]

41. Lee, W.H.; Moscardo, G. Understanding the impact of ecotourism resort experiences on tourists' environmental attitudes and behavioural intentions. J. Sustain. Tour. 2005, 13, 546-565. [CrossRef]

42. Miller, D.; Merrilees, B.; Coghlan, A. Sustainable urban tourism: Understanding and developing visitor pro-environmental behaviours. J. Sustain. Tour. 2015, 23, 26-46. [CrossRef]

43. Tao, C.-H.; Eagles, P.F.; Smith, S.L. Profiling Taiwanese ecotourists using a self-definition approach. J. Sustain. Tour. 2004, 12, 149-168. [CrossRef]

44. Boley, B.B.; Nickerson, N.P.; Bosak, K. Measuring geotourism: Developing and testing the geotraveler tendency scale (GTS). J. Travel Res. 2011, 50, 567-578. [CrossRef]

45. Del Chiappa, G.; Grappi, S.; Romani, S. Attitudes toward responsible tourism and behavioral change to practice it: A demand-side perspective in the context of Italy. J. Qual. Assur. Hosp. Tour. 2016, 17, 191-208. [CrossRef]

46. Goodwin, H.; Francis, J. Ethical and responsible tourism: Consumer trends in the UK. J. Vacat. Market. 2003, 9, 271-284. [CrossRef] 
47. Kang, M.; Moscardo, G. Exploring cross-cultural differences in attitudes towards responsible tourist behaviour: A comparison of Korean, British and Australian tourists. Asia Pac. J. Tour. Res. 2006, 11, 303-320. [CrossRef]

48. Lee, T.H.; Jan, F.-H.; Yang, C.-C. Conceptualizing and measuring environmentally responsible behaviors from the perspective of community-based tourists. Tour. Manag. 2013, 36, 454-468. [CrossRef]

49. Wurzinger, S.; Johansson, M. Environmental concern and knowledge of ecotourism among three groups of Swedish tourists. J. Travel Res. 2006, 45, 217-226. [CrossRef]

50. Scheyvens, R. Ecotourism and the empowerment of local communities. Tour. Manag. 1999, 20, $245-249$. [CrossRef]

51. Egmond, A.N.F. Understanding Western Tourists in Developing Countries; CABI: Egham, UK, 2007.

52. Doxey, G.V. A causation theory of visitor-resident irritants: Methodology and research inferences. In Proceedings of the Travel and Tourism Research Associations Sixth Annual Conference Proceedings, San Diego, CA, USA, 8-11 September 1975; pp. 195-198.

53. Ap, J.; Crompton, J.L. Residents' strategies for responding to tourism impacts. J. Travel Res. 1993, 32, 47-50. [CrossRef]

54. Gursoy, D.; Rutherford, D.G. Host attitudes toward tourism: An improved structural model. Ann. Tour. Res. 2004, 31, 495-516. [CrossRef]

55. Harrill, R. Residents' attitudes toward tourism development: A literature review with implications for tourism planning. J. Plan. Lit. 2004, 18, 251-266. [CrossRef]

56. Díaz-Pérez, F.; Bethencourt-Cejas, M.; Álvarez-González, J. The segmentation of canary island tourism markets by expenditure: Implications for tourism policy. Tour. Manag. 2005, 26, 961-964. [CrossRef]

57. Mok, C.; Iverson, T.J. Expenditure-based segmentation: Taiwanese tourists to Guam. Tour. Manag. 2000, 21, 299-305. [CrossRef]

58. Spotts, D.M.; Mahoney, E.M. Segmenting visitors to a destination region based on the volume of their expenditures. J. Travel Res. 1991, 29, 24-31. [CrossRef]

59. ASEAN. ASEAN Tourism Strategic Plan 2016-2025; ASEAN: Jakarta, Indonesia, 2016.

60. Alessa, L.; Bennett, S.M.; Kliskey, A.D. Effects of knowledge, personal attribution and perception of ecosystem health on depreciative behaviors in the intertidal zone of Pacific Rim National Park and Reserve. J. Environ. Manag. 2003, 68, 207-218. [CrossRef] 